\title{
PENGARUH PERLAKUAN AMONIASI DAN FERMENTASI \\ KULIT SINGKONG TERHADAP NILAI KECERNAAN PROTEIN KASAR DAN SERAT KASAR PADA DOMBA EKOR TIPIS JANTAN
}

\section{The Effect of Ammoniation and Fermentation of Cassava Peel on Crude Protein and Crude Fiber Digestibility Value in Thin-Tail Sheep}

\author{
Ilhamsah, Muhtarudin, Agung Kusuma Wijaya, dan Liman \\ Department of Animal Husbandry, Faculty of Agriculture, University of Lampung \\ Soemantri Brojonegoro No.1 Gedong Meneng Bandar lampung 35145 \\ e-mail : ilhamujo16@gmail.com
}

\begin{abstract}
This study aimed to determine the effect of ammoniation and fermentation of cassava peel on the digestibility of crude protein and crude fiber and the best effect of ammoniation or fermentation on the digestibility of crude protein and crude fiber in thin-tail sheep. This research was conducted in AprilAugust 2019 in the sheepfold of Department of Animal Husbandry, Faculty of Agriculture, University of Lampung. The research used 9 male thin-tail sheep, feedstuff, and sheepfold with 9 pens and feed bunk. This study used a Completely Randomized Design (CRD) consisted of 3 replications and 3 treatments. The treatments given were $\mathrm{R}_{0}$ (basal ration $+15 \%$ cassava peel), $\mathrm{R}_{1}$ (basal ration $+15 \%$ fermented cassava peel) and $\mathrm{R}_{2}$ (basal ration $+15 \%$ ammoniated cassava peel). Data were analyzed with analysis of variance and continued with Least Significant Difference Test (LSD) at $5 \%$ and or $1 \%$ significant level. The results showed that the effect of ammoniation and fermentation treatment of cassava peel had no significant effect $(\mathrm{P}>0.05)$ on crude protein digestibility and crude fiber digestibility.
\end{abstract}

Keywords: Thin-tail sheep, Crude protein, Crude fiber, Ammoniated and fermented cassava peel, digestibility

\begin{abstract}
ABSTRAK
Penelitian ini bertujuan untuk mengetahui pengaruh perlakuan amoniasi dan fermentasi kulit singkong terhadap kecernaan protein kasar dan serat kasar dan pengaruh terbaik perlakuan amoniasi atau fermentasi terhadap kecernaan protein kasar dan serat kasar pada ternak domba ekor tipis jantan. Penelitian ini dilaksanakan pada April—Agustus 2019 di Kandang Jurusan Peternakan Fakultas Pertanian Universitas Lampung. Materi penelitian menggunakan domba ekor tipis jantan berjumlah 9 ekor , pakan, dan kandang domba ekor tipis jantan individual berkapasitas 9 ekor yang dilengkapi tempat pakan. Penelitian ini menggunakan Rancangan Acak Lengkap (RAL) yang terdiri 3 ulangan dan 3 perlakuan. Perlakuan yang diberikan meliputi : $\mathrm{R}_{0}$ ( ransum basal $+15 \%$ kulit singkong); $\mathrm{R}_{1}$ (ransum basal $+15 \%$ kulit singkong fermentasi); $\mathrm{R}_{2}$ (ransum basal $+15 \%$ kulit singkong amoniasi). Data dianalisis dengan analisis of varian dan dilanjutkan dengan uji beda nyata terkecil (BTN) pada taraf $5 \%$ dan atau $1 \%$. Hasil penelitian menunjukan bahwa pengaruh pemberian dengan perlakuan kulit singkong amoniasi dan fermentasi tidak berpengaruh nyata $(\mathrm{P}>0,05)$ terhadap kecernaan protein kasar dan kecernaan serat kasar.
\end{abstract}

Kata kunci: Domba Ekor Tipis (DET), Protein kasar, Serat kasar, Kulit singkong, Amoniasi, Fermentasi, Digestibility

\section{PENDAHULUAN}

Upaya pemanfaatan limbah hasil pertanian sebagai sumber pakan alternatif merupakan langkah yang tepat dalam menekan biaya ransum dikarenakan biaya ransum adalah biaya terbesar yang harus dikeluarkan oleh peternak. Langkah alternatif ini diambil dikarenakan biaya yang harus dikeluarkan oleh peternak untuk ransum mencapai $50--80 \%$ dari total biaya produksi.
Data jumlah produksi singkong nasional pada 2015 sebesar $21.801 .415 \mathrm{Kg}$ dan data Provinsi Lampung sebesar 20157387084 (BPS 2015). Berdasarkan data tersebut dari jumlah total yang ada singkong 21 juta ton dengan bagian kulit memiliki porsi $20 \%$ dari tiap kilogram umbi singkong, maka terdapat kurang lebih 4 juta ton kulit singkong yang terbuang menjadi limbah.

Kulit singkong merupakan bagian dari hasil sisa pertanian yang ketersediaannya 
melimpah dan memiliki potensi sebagai bahan baku pakan Nurlaili et.al (2013). Kulit singkong memiliki kandungan asam sianida yang sangat tinggi yaitu sebesar 18,0 - 309,4 ppm untuk per 100 gram kulit singkong (Richana, 2013). Hidrogen sianida merupakan zat yang bersifat racun baik dalam bentuk bebas maupun kimia, yaitu glikosida, sianogen phaseulonathin, linamarin dan metillinamarin/lotaustrain (Coursey, 1974).

Salah satu solusinya adalah dengan memanfaatkan limbah hasil pertanian dan perkebunan sebagai sumber pakan alternatif bagi ternak ruminansia. Salah satu kendala yang dihadapi limbah tanaman singkong adalah nilai gizi yang rendah, seperti protein rendah dan serat kasar serta daya cerna yang rendah.

Perlu adanya pemanfaat peningkatan dalam teknologi pengolahan pembuatan pakan secara fermentasi maupun amoniasi untuk meningkatkan produktifitas dan Reproduksi ternak domba dari pengolahan pakan tersebut.

Berdasarkan hal tersebut perlu dilakukan penelitian terkait pengolahan kulit singkong berupa fermentasi dan amoniasi sebelum digunakan sebagai pakan ternak domba serta pengaruh terhadap kecernaan.

\section{MATERI DAN METODE}

\section{Waktu dan Tempat}

Penelitian ini dilaksanakan pada bulan April - Agustus 2019, bertempat di Kandang Jurusan Peternakan Fakultas Pertanian Universitas Lampung.

Materi

Peralatan yang digunakan yaitu kandang domba ekor tipis jantan individual berkapasitas 9 ekor yang dilengkapi tempat pakan, waring penampung feses, timbangan gantung digital, sekop, sapu lidi, ember, kantung plastik, buku tulis, pena, terpal, karung, drum plastik, dan besek plastik, sedangkan peralatan yang digunakan untuk analisis proksimat yaitu 1 set peralatan untuk menguji protein kasar dan satu set peralatan untuk menguji kadar serat kasar.

Bahan yang digunakan pada penelitian ini yaitu 9 ekor domba ekor tipis (DET) jantan. Ransum yang digunakan terdiri atas hijauan dan konsentrat. Hijauan berupa silase daun dan kulit singkong. Konsentrat yang digunakan yaitu onggok, dedak halus, dan molases.

\section{Metode}

\section{Rancangan Percobaan}

Penelitian ini menggunakan metode in vivo dengan teknik penelitian menggunakan Rancangan Acak Lengkap (RAL) yang terdiri dari 3 perlakuan dengan 3 ulangan. Perlakuan yang diberikan yaitu pemberian ransum yang berbeda yaitu:

$\mathrm{R} 0$ : ransum basal $+15 \%$ kulit singkong tanpa perlakuan

$\mathrm{R} 1$ : ransum basal $+15 \%$ kulit singkong fermentasi

$\mathrm{R} 2$ : ransum basal $+15 \%$ kulit singkong amoniasi

\section{Analisis Data}

Data yang diperoleh dari hasil penelitian dianalisis dengan analisis of varian (ANOVA) pada taraf $5 \%$ dan atau $1 \%$, dan dilanjutkan dengan uji beda nyata terkecil (BNT).

\section{Peubah yang Diamati}

Peubah yang diamati adalah kecernaan protein kasar, dan kecernaan serat kasar.

\section{HASIL DAN PEMBAHASAN}

\section{Pengaruh Ransum Terhadap Kecernaan Protein Kasar pada Domba Ekor Tipis Jantan.}

Kecernaan protein kadar pada kambing perlakuan dapat dilihat pada Tabel 1 . Berdasarkan hasil analisis ragam menunjukkan bahwa pemberian ransum perlakuan tidak berpengaruh nyata $(\mathrm{P}>0.05)$ terhadap kecernaan protein kasar pada DET jantan. Rata-rata kecernaan protein kasar tertinggi oleh perlakuan R2 sebesar 50.44 $\pm 13.89(\%)$ diikuti oleh R1

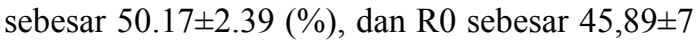
$(\%)$. Perlakuan nilai kecernaan protein kasar tertinggi terdapat pada R2 yaitu pelakuan amoniasi. Hal ini disebabkan dengan adanya proses amoniasi merenggangkan ikatan antara selulosa dan lignin.

Tabel 1. Rata-rata kecernaan protein kasar pada Domba Ekor Tipis jantan

\begin{tabular}{cccc}
\hline \multirow{2}{*}{ Ulangan } & \multicolumn{3}{c}{ Perlakuan } \\
\cline { 2 - 4 } & R0 & R1 & R2 \\
\hline 1 & 38.54 & 50.91 & 38.68 \\
2 & 47.52 & 47.50 & 46.73 \\
3 & 51.62 & 52.11 & 65.89 \\
\hline \multirow{2}{*}{ Rataan } & $45.89 \pm 7$ & $50.17 \pm 2.39$ & $50.44 \pm 13.98$
\end{tabular}

Keterangan :

R0 : ransum basal $+15 \%$ kulit singkong tanpa perlakuan

$\mathrm{R} 1$ : ransum basal $+15 \%$ kulit singkong fermentasi

$\mathrm{R} 2$ : ransum basal $+15 \%$ kulit singkong amoniasi

Hastuti et al, (2011) menyatakan bahwa amoniasi berfungsi memutuskan ikatan antara selulosa dan lignin, serta membuat ikatan serat menjadi longgar. Perlakuan R1 (fermentasi) memiliki kemampuan terendah dalam meningkatkan protein kasar pada kulit singkong sebesar $50.17 \%$ yang dibandingkan hanya 
meningkatkan sekitar $0.27 \%$ dari R2 (amoniasi) yang protein kasarnya sebesar $50.44 \%$.

Pada hasil analisis semua perlakuan (R0,R1, dan R2) P> 0,05 (tidak berbeda nyata) artinya memiliki tingkat kemampuan yang sama untuk meningkatkan protein kasar pada kulit singkong. Hal ini terjadi karena penambahan Amoniasi merupakan suatu poses perombakan dari struktur keras menjadi struktur yang lebih lunak (hanya struktur fisiknya) dan penambahan unsur N saja. Prinsip dalam teknik amoniasi ini adalah penggunaan urea sebagai sumber amoniak yang dicampurkan ke dalam bahan. nitrogen amoniak meningkatkan kadar protein kasar kulit singkong, Marjuki (2012) menyebutkan bahwa pada proses ureolisis terjadi proses penguraian urea menjadi amonia oleh enzim urease yang diproduksi oleh bakteri ureolitik yang terdapat pada bahan pakan teramoniasi, kemudian (Eko et al., 2013) menambahkan bahwa amoniak akan terserap dan berikatan dengan gugus asetil dari bahan pakan, kemudian membentuk garam amonium asetat yang pada akhirnya terhitung sebagai protein bahan.

Kandungan protein kasar yang rendah pada suatu bahan pakan menyebabkan kecernaan protein pada ternak juga rendah. Hal ini sesuai pendapat Anggorodi (1994), bahwa kecernaan protein bahan makanan tergantung pada kadungan protein ransum, bahan makanan dengan kandungan protein yang rendah mempunyai kecernaan protein yang rendah, begitu pula sebaliknya.

Menurut Church dan Pond (1995), dalam analisis proksimat data abu diperlukan untuk menghitung atau mengukur nilai bahan ekstrat tanpa nitrogen. Bahan Ekstrat Tanpa Nitrogen merupakan sumber energi bagi mikroba rumen, apabila kandungan abu dalam ransum tinggi makan bahan ekstrat tanpa nitrogen akan menurun sehingga akan mengurangi sumber energi bagi mikroba rumen. Mikroba rumen diperlukan dalam mencerna protein menjadi senyawa lebih sederhana sehingga dapat dimanfaatkan oleh mikroba rumen maupun induk semang yang berimplikasi positif terhadap kecernaan protein kasar.

\section{Pengaruh Ransum terhadap Kecernaan Serat Kasar pada Kambing PE Jantan.}

Kecernaan bahan pakan adalah bagian zat yang dapat dicerna oleh tubuh dan diansumsikan diserap oleh tubuh ternak sehingga tidak diekskresikan dalam feses. Jumlah maupun komposisi kimia serat suatu bahan pakan sangat berpengaruh terhadap kecernaan (Tillman et al., 1989).

Berdasarkan hasil analisis ragam pada Tabel 2. nilai rata-rata perlakuan R0 (Kulit singkong tanpa perlakuan) $34.06 \pm 0.48 \%$ memiliki kecernaan serat kasar terendah dalam menurunkan serat kasar dibandingkan dengan R1 (kulit singkong fermentasi) 40.86 $\pm 7.35 \%$ dan R2 (kulit singkong amoniasi) 43.22 $\pm 7.58 \%$. Sedangkan perlakuan R2 mempunyai nilai kecernaan tertinggi dibandingkan dengan perlakuan R0 dan R1. Serat kasar terdiri dari selulosa, hemiselulosa dan lignin ( Tillman et al., 1998).

Tabel 2. Rata-rata kecernaan serat kasar pada Domba Ekor Tipis jantan.

\begin{tabular}{cccc}
\hline \multirow{2}{*}{ Ulangan } & \multicolumn{3}{c}{ Perlakuan } \\
\cline { 2 - 4 } & $\mathrm{R} 0$ & $\mathrm{R} 1$ & $\mathrm{R} 2$ \\
\hline 1 & 33.92 & 48.95 & 41.61 \\
2 & 34.59 & 34.59 & 36.58 \\
3 & 33.67 & 39.05 & 51.47 \\
\hline \multirow{2}{*}{ Rataan } & $34.06 \pm 0.48$ & $40.86 \pm 7.35$ & $43.22 \pm 7.58$
\end{tabular}

Keterangan :

R0 : ransum basal $+15 \%$ kulit singkong tanpa perlakuan

$\mathrm{R} 1$ : ransum basal $+15 \%$ kulit singkong fermentasi

$\mathrm{R} 2$ : ransum basal $+15 \%$ kulit singkong Amoniasi

Hal ini menunjukkan bahwa perlakuan dengan proses amoniasi dapat meningkatkan kecernaan dan kadar serat yang terdapat pada kulit singkong. Prasetyawan et al, (2012). menyatakan bahwa perlakuan amoniasi dapat meningkatkan kecernaan dengan melonggarkan ikatan lignoselulosa, menjadikan karbohidrat mudah dicerna, meningkatkan kecernaan dengan membengkakkan jaringan tanaman dan meningkatkan palatabilitas pakan.

Daya cerna serat kasar dipengaruhi oleh beberapa faktor antara lain kadar serat dalam pakan, komposisi penyusun serat kasar dan aktivitas mikroorganisme (Parakkasi, 1991). Semakin tinggi serat kasar akan menurunkan daya cerna bahan kering, protein kasar dan energi dapat dicerna (Price et al., 1980). Hal ini disebabkan untuk mencerna serat kasar secara efesien, mikroorganisme membutuhkan sumber energi yang cukup dari makanan yang masuk ke rumen.

Kandungan serat kasar ransum R0 kulit singkong tanpa perlakuan lebih rendah di bandingkan dengan R1 (fermentasi) dan R2 (amoniasi). Rendahnya kandungan serat kasar mengakibatkan kandungan nutrien pakan akan dapat dicerna secara maksimal. Arora (1989), menyatakan bahwa serat kasar mengandung selulosa dan hemiselulosa merupakan karbohidrat yang terkandung dalam bahan makanan yang dapat dicerna dan di manfaatkan sebagai sumber energi oleh mikroorganisme dalam rumen.

Serat kasar bagi ruminansia digunakan sebagai sumber energi utama dan lemak kasar merupakan sumber energi yang efisien dan 
berperan penting dalam metabolisme tubuh sehingga perlu diketahui kecernaanya dalam tubuh ternak (Suprapto et al., 2013). Serat kasar berperan menstimulasi proses ruminasia dan kontraksi rumen yang pada akhirnya akan meningkatkan proses fermentasi serat pakan. Hasil utama dari fermentasi adalah asam asetat, propionat, dan butirat yang selanjutnya berfungsi sebagai sumber energi bagi mikroba rumen. Peningkatan jumlah mikroba rumen akan meningkatkan pula sekresi enzim pencernaan serat kasar yang dihasilkan oleh bakteri sehingga berdampak positif terhadap peningkatan degradasi ransum terutama fraksi serat kasar.

\section{SIMPULAN}

Berdasarkan hasil penelitian yang telah dilakukan dapat diambil kesimpulan sebagai berikut:

1. Pemberian perlakuan amoniasi dan fermentasi kulit singkong pada Domba Ekor Tipis jantan tidak berpengaruh nyata $(\mathrm{P}>0,05)$ terhadap kecernaan protein kasar dan serat kasar.

2. Pemberian perlakuan amoniasi dan fermentasi kulit singkong pada Domba Ekor Tipis jantan tidak memberikan pengaruh terbaik terhadap kecernaan serat kasar dan protein kasar, $\mathrm{n}$ yang terbaik yaitu pada perlakuan amoniasi dengan nilai kecernaan protein kasar $50.44 \%$ dan serat kasar $43.22 \%$.

\section{DAFTAR PUSTAKA}

Anggorodi, R. 1994. Ilmu Pakan Ternak Umum. Gramedia Pustaka Utama. Jakarta

Arora, S. P. 1989. Pecernaan Mikroba pada Ruminansia. Gajah Mada University Press. Yogyakarta

Badan Pusat Statistik. 2015. Jumlah Produksi Tanaman Umbi Kayu/singkong https://www.bps.go.id/linkTableDinami s/view/id/880. (diakases pada 17 Oktober 2019).

Church, D.C., and W.G. Pond. 1995. Digestive Physiology and Nutrition of Ruminants. Vol.I Digestive Physiology 2nd Edition. USA.

Coursey. D.G. 1974. Cassava as Food; Toxicity and Technology. Proc. of Interdiciplinary Workshop, London. pp. 27-36. https://sivitasakademika. wordpress.com/2016/11/07/penggunaan -kulit-singkong-sebagai-pakanruminansia/.html. (diakses pada 6 Maret 2019).
Eko, D. P., M Junus. dan M Nasich 2013. Pengaruh penambahan urea terhadap kandungan protein kasar dan serat kasar padatan lumpur organik unit gas bio. Jurnal Ilmiah Ilmu-Ilmu Peternakan. 17 (1) : $1-11$.

Hastuti, D., Shofia, N. A., dan Baginda,I. M. 2011. Pengaruh perlakuan teknologi amofer (amoniasi fermentasi) pada limbah tongkol jagung sebagai alternatif pakan berkualitas ternak ruminansia. Jurnal Ilmu-Ilmu Peternakan Mediagro. 7 (1):55 - 65.

Marjuki. 2012. Peningkatan Kualitas Jerami Padi Melalui Perlakuan Urea Amoniasi. (SKRIPSI) Fakultas Peternakan. Universitas Brawijaya. Malang.

Nurlaili, F., Suparwi, dan T.R. Sutardi. 2013. Fermentasi Kulit Singkong (Manihot Utilissima Pohl) Menggunakan Aspergillus Niger Pengaruhnya Terhadap Kecernaan Bahan Kering (KBK) dan Kecernaan Bahan Organik (KBO) Secara In-Vitro. Jurnal Ilmiah Peternakan, 1(3): 856-864.

Parakkasi, A. 1991. Ilmu Nutrisi dan Makanan Ternak Ruminansia. Universitas Indonesia Press. Jakarta.

Prasetyawan, R.M., B.I.M. Tampoebolon dan Surono., 2012. Peningkatan kualitas tongkol jagung melalui teknologi amoniasi fermentasi (AMOFER) terhadap kecernaan bahan kering dan bahan organik serta protein total secara in vitro. J. of Animal Agriculture. 1 (1):611-621.

Price, M. A., S. D Jones., G. W. Mathison, and R. T. Berg. 1980. The effect of inceasing dietary roughage and slaughter weight on the feedlot performance and carcass characteristics of bull and steer. Canadian J. of Anim Sci. 60: 349-358

Richana, N. 2013. Mengenai Potensi Ubi Kayu dan Ubi Jalar. Bandung : Nuansa Cendikia.

Suprapto, H., F. M. Suhartati. dan T. Widiyastuti. 2013. Kecernaan serat kasar dan lemak kasar complete feed limbah jerami dengan sumber protein berbeda pada kambing peranakan etawa lepas sapih. Jurnal Imu Peternakan. 1(3): 938-946

Tillman, A.D., H. Hartadi, S. Reksodiprodjo, S. Prwawirokusomo, dan Lebdosoekojo. 1989. Ilmu Makanan Ternak Dasar. Gajah Mada University Press. Yogyakarta. 